CASE REPORT

\title{
Little league shoulder syndrome in an adolescent cricket player
}

\author{
W R Drescher, A Falliner, T Zantop, K Oehlert, W Petersen, J Hassenpflug
}

Br J Sports Med 2004;38:e14 (http://www.bjsportmed.com/cgi/content/full/38/4/el4). doi: 10.1136/bjsm.2003.008193

The first case of little league shoulder syndrome in a cricket player is reported. The condition has been reported in baseball pitchers and is characterised by a proximal humeral epiphyseolysis.

A 12 year old male first junior class cricket player presented at our outpatient clinic with a 4 week history of right shoulder pain. Pain occurred for the first time during fast bowling with the right arm and was recurrent. Clinical examination revealed a physiologic active and passive range of motion in both shoulders. No swelling or tender points could be discerned. $x$ Rays of the shoulder joints demonstrated a significant widening of the lateral part of the proximal humeral epiphysis of the right shoulder (fig 1). Treatment consisted of recommending total abstinence from all throwing for 12 weeks and abstinence from fast bowling until closing of the proximal humeral epiphyseal plate. ${ }^{1}$ After the shoulder pain subsided, the young patient was allowed to resume playing at a different position. The patient was pain free 1 year after the onset of symptoms. Resumption of playing as a fast bowler again was recommended only after closure of the proximal humeral epiphyseal plate.

\section{DISCUSSION}

To our knowledge, the present paper is the first case report of little league shoulder syndrome in a cricket player. This syndrome has previously been described in adolescent baseball pitchers. ${ }^{2}$

In an overview of injuries in the young athlete, the proximal humerus is an uncommon site of injury. ${ }^{3}$ A case of a slipped capital humeral epiphysis with radiologic physeal irregularities similar to those of little league shoulder syndrome has been reported in a gymnast. ${ }^{4}$ Little league elbow has been described as fragmentation and partial avulsion of the medial humeral epicondyle. ${ }^{5}$ Little league elbow occurs in throwing and racquet sports which produce
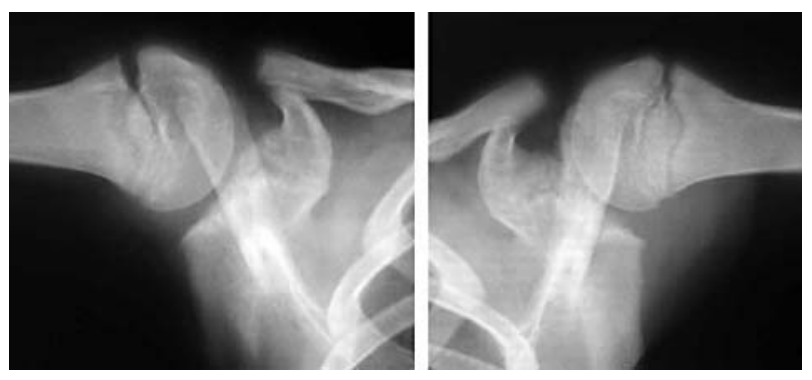

Figure 1 The $x$ rays show a widening of the lateral part of the proximal humeral epiphysis in the right shoulder compared to the contralateral side. large stresses at the elbow joint including tension on the ulnar side and compression on the radial side.

The throwing mechanism of baseball or cricket ball players, as required by fast bowlers, is a whip-like activity of the arm which places repetitive traction strain on the shoulder and elbow joints. ${ }^{1}$ The proximal humeral growth plate of the young person is at high risk for epiphysiolysis because it consists of cartilage, and an impulse of the whole arm exerts strain at this weak location.

In cricket, injury prevalence has been reported to be highest for pace bowlers (14\%), while being $4 \%$ for spin bowlers, $4 \%$ for batsmen, and $2 \%$ for wicket keepers in Australian cricket at first class level. ${ }^{6}$ The most common injuries were hamstring strains, side strains, groin injuries, wrist and hand injuries, and lumbar soft tissue injuries. ${ }^{7}$ In a longitudinal study in 436 elite cricket players, injuries occurred in the lower limbs (49.8\%), upper limbs $(23.3 \%)$, and the back and trunk $(22.8 \%) .^{8}$ Acute injuries made up $64.8 \%$.

Concerning treatment, Adams recognised the traumatic nature of the condition and showed that rapid recovery was achieved by rest. ${ }^{1}$ In a 13 year old baseball pitcher, treatment with 3 weeks of immobilisation in a sling and abstinence from all throwing for the following 12 weeks led to an asymptomatic condition after 2 years. ${ }^{2}$ As early mobilisation of the shoulder joint is favoured today, ${ }^{9}$ the authors preferred not to immobilise the shoulder of the above patient in a sling. Other authors have also refrained from immobilisation and have treated the condition only with rest, allowing the adolescent baseball player to resume playing at other positions but not to pitch again until closing of the epiphyses. ${ }^{1}$ No case has hitherto been reported in which little league shoulder was operatively managed.

The primary goal of sports physicians, parents, and coaches is to protect young cricket players from injuries. Recommendations for protecting young baseball pitchers from shoulder injuries include resistance exercises and a throwing program with a long toss component as well as post throwing scapular stabilisation and rotator cuff exercises. ${ }^{10}$ Many young athletes lack adequate muscular strength to dynamically stabilise the shoulder. ${ }^{10}$ Pitch counts and soreness rules may further limit maximum effort. ${ }^{10}$

In conclusion, this case report shows that evaluation of shoulder pain in the young throwing athlete should always include a high index of suspicion for growth plate injury.

\section{Authors' affiliations}

W R Drescher, A Falliner, T Zantop, K Oehlert, W Petersen,

J Hassenpflug, Department of Orthopaedics, University Hospital Kiel, Kiel, Germany

Conflict of interest: none declared.

Correspondence to: W R Drescher, Department of Orthopaedics, University Hospital Kiel, Christian-Albrechts-University, Michaelisstr. 1, D-24105 Kiel, Germany; wolfdrescher@hotmail.com 
Revised version received 1 August 2003

Accepted for publication 3 August 2003

\section{REFERENCES}

1 Adams JE. Bone injuries in very young athletes. Clin Orthop 1968;58: 129-40.

2 Barnett LS. Little League shoulder syndrome: proximal humeral epiphyseolysis in adolescent baseball pitchers. A case report. J Bone Joint Surg Am 1985:67:495-6.

3 Adirim TA, Cheng TL. Overview of injuries in the young athlete. Sports Med 2003;33:75-81.

4 Dalldorf PG, Bryan WJ. Displaced Salter-Harris type I injury in a gymnast. A slipped capital humeral epiphysis? Orthop Rev 1994;23:538-41.
5 Loomer RL. Elbow injuries in athletes. Can J Appl Sport Sci 1982;7:164-6.

6 Orchard J, James T, Alcott E, et al. Injuries in Australian cricket at first class level 1995/1996 to 2000/2001. Br J Sports Med 2002;36:270-4.

7 Foster D, John D, Elliott B, et al. Back injuries to fast bowlers in cricket: a prospective study. Br I Sports Med 1989;23:150-4.

8 Stretch RA. Cricket injuries: a longitudinal study of the nature of injuries to South African cricketers. Br J Sports Med 2003;37:250-3.

9 Jubel A, Andermahr J, Schiffer G, et al. Elastic stable intramedullary nailing of midclavicular fractures with a titanium nail. Clin Orthop 2003;408:279-85.

10 Axe MJ. Recommendations for protecting youth baseball pitchers. Sports Med Arthrosc Rev 2001;9:147-153. 